\title{
Fito Pengolahan untuk Dekosentrasi Warna Rhodamin B, Metilen Biru dan Metil Violet dengan Tumbuhan Air Eichhornia crassipes
}

\author{
Amanda Herrena dan Harmin Sulistiyaning Titah \\ Departemen Teknik Lingkungan, Fakultas Teknik Sipil dan Perencanaan Masing-masing, Institut \\ Teknologi Sepuluh Nopember (ITS) \\ Jl. Arief Rahman Hakim, Surabaya 60111 Indonesia \\ e-mail: harmin_st@its.ac.id
}

\begin{abstract}
Abstrak-Pengolahan air limbah dengan menggunakan tumbuhan air atau phytotreatment telah menjadi salah satu alternatif pengolahan air limbah yang cukup murah dan efisien dalam penerapannya. Tumbuhan air lebih efektif dalam pengolahan air limbah dibandingkan dengan tanaman lainnya karena pertumbuhan mereka lebih cepat dan produksi biomassa yang lebih besar. Kemampuannya relatif lebih tinggi untuk meyerap polutan karena kontak langsung dengan air yang terkontaminasi. Pada penelitian untuk mengetahui efisiensi tumbuhan air yaitu Eceng gondok (Eichhornia crassipes) dalam dekonsentrasi warna. Dilakukan tahapan yaitu propagasi tumbuhan, tahap aklimatisasi, tahap range finding test dan uji phytotreatment selama 30 hari dengan parameter utama uji warna dan parameter pendukung yaitu uji suhu, pH, analisa morfologi, berat basah dan berat kering. Dilakukan juga uji toksisitas pada LC-50 dan uji plant cells analysis. Hasil penelitian menunjukkan bahwa uji toksisitas LC-50 dari ketiga warna tersebut, bahwa tumbuhan eceng gondok memiliki ketahanan respons biologis yang lebih besar. Nilai LC-50 tumbuhan $E$. crassipes terhadap pewarna rhodamin $\mathrm{B} 99,5 \mathrm{mg} / \mathrm{L}>$ metil violet $83,2 \mathrm{mg} / \mathrm{L}>$ metilen biru $74,5 \mathrm{mg} / \mathrm{L}$. Hasil penyisihan warna pada hari ke 30 oleh tumbuhan E.crassipes terhadap warna metilen biru mencapai 59\% sedangkan pada kontrol mencapai 59\%, warna rhodamin $B$ mencapai $52 \%$ dan pada kontrol mencapai $52 \%$ dan metil violet sebesar $\mathbf{5 1 \%}$ sedangkan pada kontrol mencapai $51 \%$. Berdasarkan hasil persentase penyisihan warna yang dihasilkan maka dapat disimpulkan bahwa penyisihan warna rhodamin $B$, metilen biru dan metil violet oleh tumbuhan E.crassipes sampai 30 hari pemaparan kurang efektif karena mikroorganime indigenous yang lebih berperan dan terjadinya proses reduksi oksidasi terhada pewarna sintesis.
\end{abstract}

Kata Kunci- Eichhorna crassipes, rhodamin B, metilen biru, metil violet

\section{PENDAHULUAN}

$\mathrm{B}$ ANYAKNYA industri seperti tekstil, kertas, plastik, kulit tanning menggunakan pewarnaan secara luas dan mengoperasikan secara berbeda-beda [1]. Pada industri tersebut, zat warna ini memiliki berbagai polutan pada proses yang berbeda-beda [2]. Air limbah tekstil mencakup berbagai macam pewarna dan tambahan bahan kimia yang membuat tantangan lingkungan untuk industri tekstil tidak hanya untuk limbah cair tetapi juga komposisi kimianya dan polusi utama dalam air limbah tekstil berasal dari pencelupan dan finishing [3].
Pada fito pengolahan merupakan salah satu alternatif pengolahan limbah yang efektif, mudah diterapkan dan ekonomis [4]. Fito pengolahan memusatkan pada tumbuhan sebagai teknologi lingkungan hidup yang mampu menyelesaikan masalah lingkungan secara alami [5]. Kelebihan fito pengolahan selain dapat menurunkan polutan organik juga dapat menyerap warna [6]. Tumbuhan banyak digunakan untuk mengolah air buangan karena mampu mengolah air buangan dengan tingkat efisiensi yang tinggi [7]. Tumbuhan air lebih efektif dalam pengolahan air limbah dibandingkan dengan tanaman lainnya karena pertumbuhan mereka lebih cepat dan produksi biomassa yang lebih besar dan kemampuannya relatif lebih tinggi daripada penyerapan polutan karena, kontak langsung dengan air yang terkontaminasi [8].

Tanaman E.crassipes ini juga memiliki banyak kandungan materi yang dapat berfermentasi dan mampu menghasilkan biogas [9]. E.crassipes dapat menurunkan sebesar warna metilen biru 98,42 \% dan metilen orange 66,80 \% [10]. Berdasarkan latar belakang diatas, maka tujuan dari penelitian ini adalah mengetahui tingkat toksisitas tumbuhan air $E$. crassipes terhadap larutan warna rhodamin $\mathrm{B}$, metilen biru dan metil violet dan menentukan efisiensi penyisihan warna rhodamin B, metilen biru dan metil violet oleh tumbuhan air $E$. crassipes.

\section{METODE PENELITIAN}

\section{A. Tahap Propagasi}

Tahap propagasi ini dilakukan minimal selama satu bulan sampai tumbuhan memiliki ukuran secara optimum [11]. Pada masa propagasi akan dilakukan pengamatan terhadap laju pertumbuhan tumbuhan dan dibiarkan sampai tumbuh tunas [12]. Pengamatan terhadap tumbuhan E.crassipes dilakukan dengan mengamati karakteristik fisik berupa panjang tumbuhan, lebar daun dan tumbuhan pada umur dan tinggi yang sama akan digunakan pada setiap tahapan penelitian, dan diharapkan dengan demikian maka kondisi awal tumbuhan yang digunakan adalah sama [13].

\section{B. Tahap Aklimatisasi}

Tahap aklimatisasi tumbuhan ini dilakukan agar tumbuhan E.crassipes dapat menyesuaikan diri dengan kondisi dan media 
yang akan digunakan pada tahap Range Finding Test (RFT) dan uji fitopengolahan. Proses tahap aklimatisasi tumbuhan ini dilakukan dengan cara meletakkan tumbuhan pada reaktor yang akan digunakan pada penelitian uji fito pengolahan dan dilakukan selama 7 hari menggunakan air PDAM [14].

\section{Tahap Range Finding Test}

Tahap Range Finding Test (RFT) ini bertujuan untuk mengetahui seberapa besar kemampuan dalam menyerap polutan pada konsentrasi tertentu. Variasi konsentrasi yang akan digunakan adalah 0 pada kontrol, 30, 50, 70, 90, 110 $\mathrm{mg} / \mathrm{L}$. Pada masing-masing konsentrasi akan diamati parameter pertumbuhan tumbuhan. Pada konsentrasi yang membuat tumbuhan masih segar (tidak layu dan mati) inilah yang akan digunakan pada uji fito pengolahan.

\section{Uji Fitopengolahan}

Penelitian utama yaitu tahap uji fito pengolahan dengan pengoperasian sistem batch. Pada tahap ini yang harus dilakukan adalah mempersiapkan larutan warna dengan konsentrasi berdasarkan hasil uji range finding test pada penelitian sebelumnya. Penelitian ini dilakukan selama 3 minggu dan bertujuan untuk mengetahui lama pengamatan ini untuk mengetahui kemampuan optimum tumbuhan dalam menyerap pencemar dan di uji warna dan uji toksisitas $\mathrm{LC}_{50}$.

\section{E. Parameter yang diukur}

Parameter yang diukur dalam penelitian ini adalah parameter utama pada konsentrasi larutan warna, parameter pendukung yaitu uji toksisitas $\mathrm{LC}_{50}$.

\section{HASIL DAN PEMBAHASAN}

\section{A. Analisis Tahap Propagasi Tumbuhan}

Tahap propagasi pada tumbuhan E.crassipes ini berfungsi yaitu untuk memperbanyak tumbuhan yang diperlukan saat penelitian dan mengetahui laju pertumbuhan, dan dilakukan minimal satu bulan. Selama tahap propagasi akan dilakukan pengamatan terhadap laju pertumbuhan tumbuhan (growth rate) dan dibiarkan sampai tumbuh tunas (second generation).

Tumbuhan yang menjadi tumbuh tunas atau second generation nantinya akan digunakan untuk uji Range Finding Test dan uji phytotreatment. Pengamatan terhadap growth rate dilakukan pada pengamatan tumbuhan secara fisik. Pengamatan terhadap growth rate dilakukan dengan mengamati karakteristik fisik E.crassipes berupa panjang tumbuhan pada Gambar 1, lebar daun pada Gambar 2. Lama pengamatan tumbuhan E.crassipes selama 3 bulan.

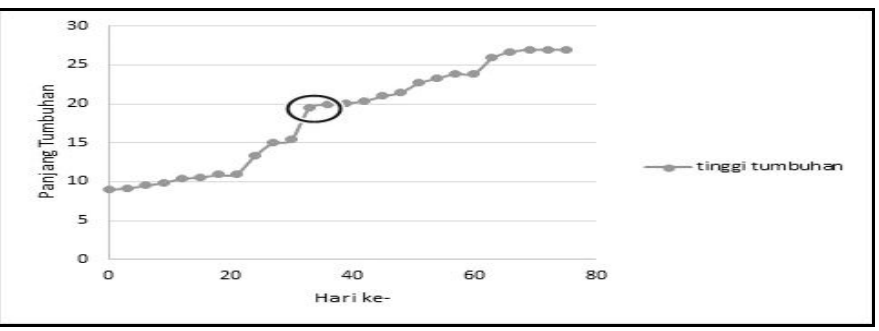

Gambar 1. Panjang Tumbuhan E.crassipes

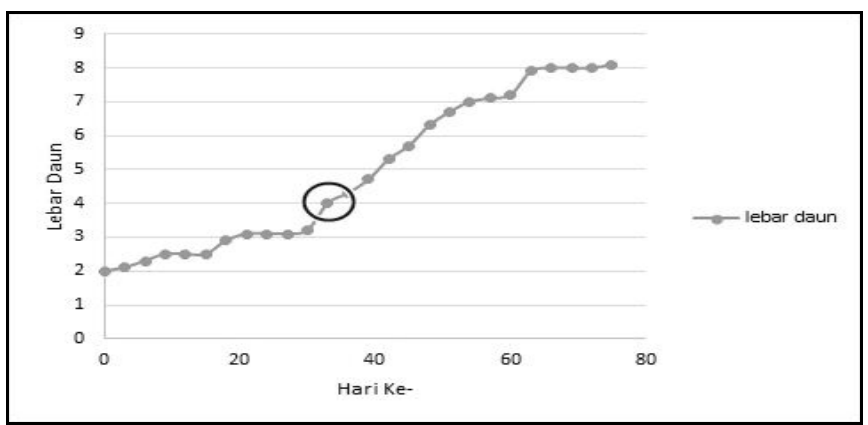

Gambar 2. Lebar Daun Tumbuhan E.crassipes

\section{B. Analisis Tahap Aklimatisasi Tumbuhan}

Tahap aklimatisasi tumbuhan dilakukan sebagai langkah tumbuhan dapat beradaptasi dengan kondisi atau media lingkungan tempat percobaan dan dimana tumbuhan dapat menyesuaikan dengan kondisi dan media yang akan digunakan untuk tahap range finding test (RFT) dan uji phytotreatment. Pengamatan pada tumbuhan E.crassipes dan P.stratiotes yaitu melihat keadaan tumbuhan yang hidup dalam keadaan tidak mati dan tidak layu dipilih untuk digunakan pada uji Range Finding Test (RFT) dan uji phytotreatment.

\section{Analisis Tahap Range Finding Test}

Tahap Range Finding Test (RFT) dilakukan untuk mengetahui seberapa besar kemampuan dalam menyerap polutan pada konsentrasi tertentu. Tumbuhan E.crassipes dan yang digunakan adalah tumbuhan hasil dari proses aklimatisasi sebelumnya dikarenakan agar tumbuhan sudah beradaptasi dengan sebelumnya. Umur tumbuhan dipilih untuk tahap RFT memiliki umur yang sama dikarenakan tumbuhan memiliki kemampuan yang sama untuk bertahan pada larutan warna selama tahap range finding test.

Masing-masing tiap bak reaktor memiliki konsentrasi yang berbeda-beda. Variasi konsentrasi yang digunakan adalah 0 $\mathrm{mg} / \mathrm{L}$ sebagai kontrol, $30 \mathrm{mg} / \mathrm{L}, 50 \mathrm{mg} / \mathrm{L}, 70 \mathrm{mg} / \mathrm{L}, 90 \mathrm{mg} / \mathrm{L}$, dan $110 \mathrm{mg} / \mathrm{L}$. Dan bak reaktor yang digunakan yaitu berupa ember plastik dengan ukuran $12 \mathrm{~L}$ dan volume air yan digunakan yaitu $6 \mathrm{~L}$ dan tahap ini dilakukan selama 7 hari. Adapun rumus untuk menentukan berapa tumbuhan yang digunakan pada tahap range finding test (RFT) yakni :

Massa E.crassipes $=$ Densitas E.crassipes x volume air (1)

Jumlah E.crassipes $=\frac{\text { massa E.erossipes }}{\text { berat basah E.crossipes }}$

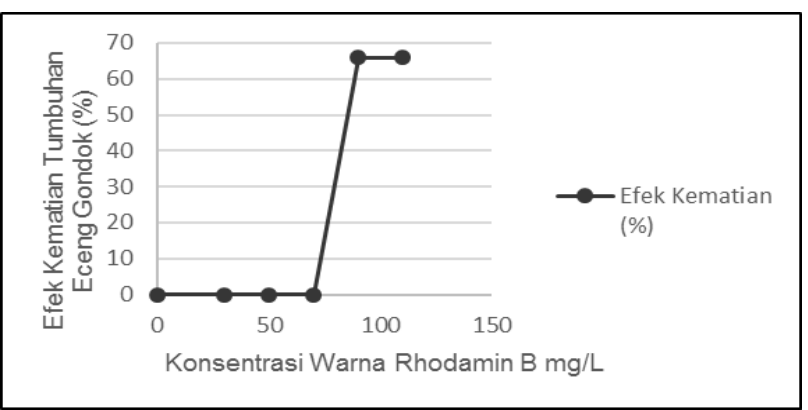

Gambar 3. Efek Kematian pada Tumbuhan E.crassipes dengan Pewarna Rhodamin B 


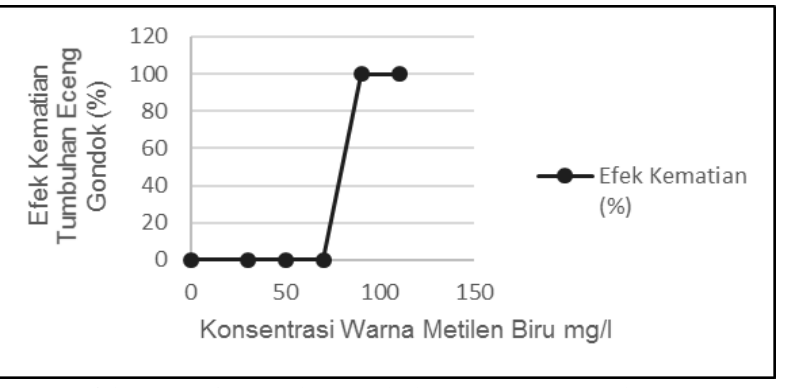

Gambar 4. Efek Kematian pada Tumbuhan E.crassipes dengan Pewarna Rhodamin B

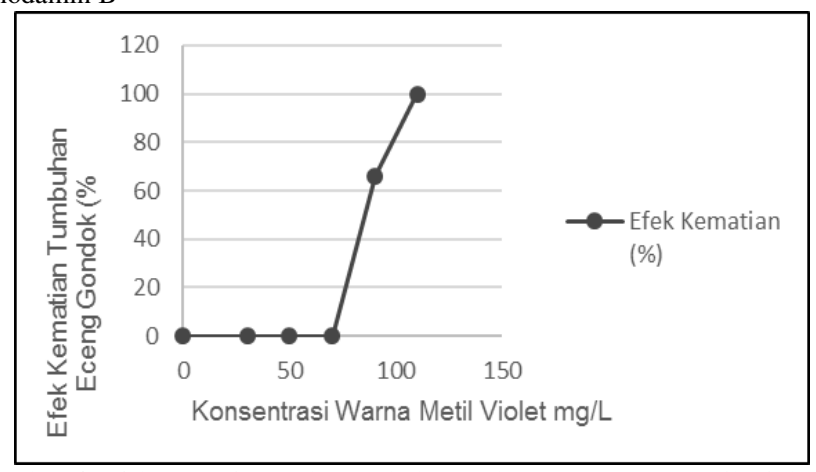

Gambar 5. Efek Kematian pada Tumbuhan $E$ dengan Pewarna Metil Violet

\section{Analisis Uji Toksisitas LC-50}

Pada Tahap ini juga dilakukan uji toksisitas LC50. LC50 adalah konsentrasi dari suatu senyawa kimia di udara atau dalam air yang dapat menyebabkan 50\% kematian pada suatu populasi makhluk hidup tertentu. Penggunaan LC50 dimaksudkan untuk pengujian ketoksikan dengan perlakuan terhadap tumbuhan uji secara berkelompok yaitu pada saat tumbuhan uji dipaparkan suatu bahan kimia melalui udara maka tumbuhan uji tersebut akan menghirupnya atau percobaan toksisitas dengan media air [15] dan dengan rumus: 1. memasukakan data hasil acute toxicity test dan menghitung prosentase kematian.

Contoh :

Konsentrasi $90 \mathrm{mg} / \mathrm{L}$

$\sum$ mortalitas $=2$ tumbuhan

$\sum$ biota $=3$ tumbuhan

Maka $: R=\frac{2}{9} \times 100 \%=66 \%$

Perhitungan prosentase proporsi kematian dapat dilihat pada Tabel 4.7 berikut ini :

2. Memasukkan data konsentrasi toksikan dan proporsi kematian biota pada grafik log-log serta mencari garis korelasi dan persamaannya. Garis korelasi tersebut merupakan garis harapan.

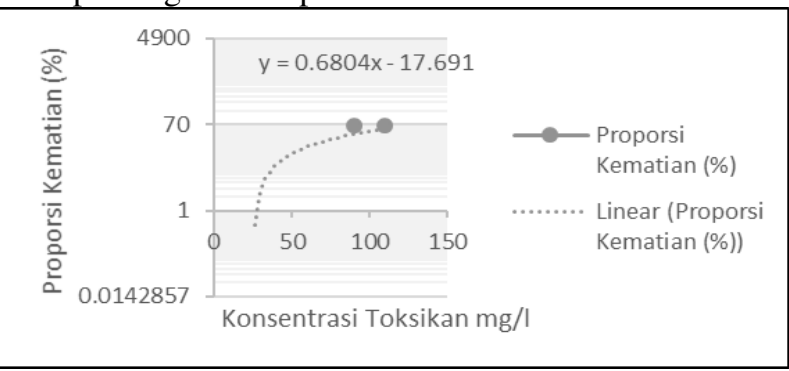

Gambar 5. Log-log proporsi harapan pada tumbuhan E.crassipes dengan larutan warna rhodamin B
3. Mengidentifikasi proporsi respon harapan (RH) tiap konsentrasi zat dengan cara memasukkan data konsentrasi toksikan (sebagai $\mathrm{x}$ ) ke dalam persamaan $\mathrm{RH}=0,6804 \mathrm{x}-$ 17,691 (sebagai y)

Contoh perhitungan :

Konsentrasi $30 \mathrm{mg} / \mathrm{L}$, maka :

$$
\begin{aligned}
& y=0,6804 x-17,691 \\
& =0,6804(30)-17,691 \\
& y=3
\end{aligned}
$$

4. Menghitung nilai perbedaan mutlak antara respon uji (R) dan respon harapan (RH) untuk setiap konsentrasi toksikan.

5. Menghitung $\mathrm{Chi}^{2}$ tiap konsentrasi dengan bantuan Nomograf $\mathrm{Chi}^{2}$.

6. Menghitung $\mathrm{Chi}^{2}$ perhitungan yang menggunakan rumus : $\mathrm{Chi}^{2}$ perhitungan $=\left(\sum \mathrm{Chi}^{2}\right) \times\left(\frac{\sum \text { Eiota }}{\sum \text { toksikan }}\right)=1,8 \times\left(\frac{15}{5}\right)=5,4$

7. Menghitung tingkat kebebasan $(\mathrm{N})$ untuk memperoleh $\mathrm{Chi}^{2}$ (95\%) yang akan dibandingkan dengan nilai $\mathrm{chi}^{2}$ perhitungan. Tingkat kebebasan didapat dengan rumus :

$\mathrm{N}=\mathrm{K}-2$,Dimana $\mathrm{K}$ merupakan jumlah variasi toksikan $=5-2=3$

Selanjutnya nilai tingkat kebebasan $(\mathrm{N})$ digunakan dalam memperoleh $\operatorname{chi}^{2}(95 \%) . \mathrm{N}=3$ diperoleh nilai $\operatorname{chi}^{2}(95 \%)$ sebesar 7,82.

Keterangan :

a. Jika chi ${ }^{2}$ perhitungan $<\operatorname{chi}^{2}(95 \%)$ maka garis korelasi konsentrasi efek harapan dapat diterima untuk perhitungan lanjut.

b. Jika tidak demikian, maka dicoba kembali hingga memenuhi $\mathrm{chi}^{2}$ perhitungan $<\operatorname{chi}^{2}(95 \%)$

c. Jika dengan banyak pengulangan chi2 perhitungan < chi2 (95\%) belum terpenuhi, maka uji toksisitas harus diulang.

Berdasarkan hasil perhitungan dapat dilihat bahwa nilai $\mathrm{chi}^{2}$ perhitungan $(5,4)<\operatorname{chi} 2(95 \%)(7,82)$, sehingga garis korelasi konsentrasi respon harapan yang telah didapat.

- Berdasarkan garis korelasi maka ditetapkan batasbatas kepercayaan 95\% dari nilai LC-50. Hal ini mengacu pada persamaan garis proporsi respon harapan dengan memasukkan nilai LC (sebagai y).

Contoh perhitungan LC-50 :

$\mathrm{y}=0,6804 \mathrm{x}-17,691$

$50=0,6804 x-17,691$

$\mathrm{x}=99,5$

Nilai batas-batas adalah sebagai berikut :

LC-45 $=92,1$

LC-50 $=99,5$

LC- $55=106,8$

- Menghitung kemiringan garis korelasi konsentrasi efek harapan.

$\begin{aligned} \mathrm{S} & =\left(\frac{L C 55}{\nu C 50}+\frac{L C 50}{\nu C 45}\right) \times \frac{1}{2} \\ & =\left(\frac{106,8}{99,5}+\frac{99,5}{92,1}\right) \times \frac{1}{2}=1,07\end{aligned}$

- Menghitung Faktor LC-50

$\mathrm{F}(\mathrm{LC}-50)=\mathrm{S}\left(\frac{2.77}{\mathrm{~N} 0.5}\right)$

$$
\begin{aligned}
& =1,07\left(\frac{2,77}{200.5}\right) \\
& =0,66
\end{aligned}
$$


- Menghitung batas-batas kepercayaan $95 \%$ LC-50

- Batas atas $=\mathrm{LC}-50 \mathrm{xf}$

$$
\begin{aligned}
& =99,5 \times 0,66 \\
& =65,67
\end{aligned}
$$

- Batas bawah = LC-50:f

$$
\begin{aligned}
& =99,5: 0,66 \\
& =150,75
\end{aligned}
$$

LC-50, tumbuhan E.crassipes pada rhodamin B 99,5 mg/L. Sedangkan pada perhitungan LC-50, tumbuhan E.crassipes pada metilen biru $74,5 \mathrm{mg} / \mathrm{L}$ dan pada metil violet $83,2 \mathrm{mg} / \mathrm{L}$.

\section{E. Analisis Uji Fitopengolahan}

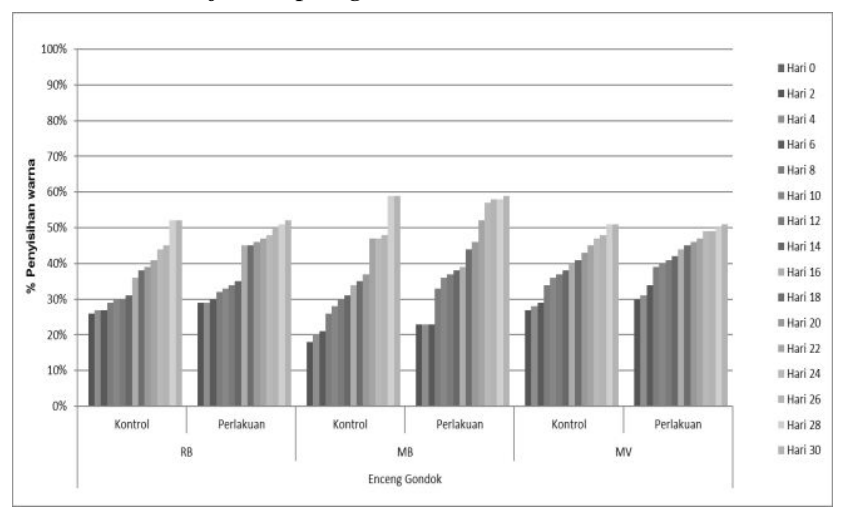

Gambar 6. \% Penyisihan Warna pada Tumbuhan E.crassipes

Berdasarkan hasil di atas, persentase penyisihan warna metilen biru oleh E.crassipes mencapai persentase tertinggi dibandingkan dengan dua warna lainnya. Hal ini disebabkan karena dilihat dari struktur kimianya, diketahui bahwa metilen biru $\left(\mathrm{C}_{16} \mathrm{H}_{18} \mathrm{~N}_{3} \mathrm{SCl}\right)$ mempunyai rantai $\mathrm{C}$ yang lebih pendek dari rhodamin $\mathrm{B} \quad\left(\mathrm{C}_{28} \mathrm{H}_{31} \mathrm{~N}_{2} \mathrm{O}_{3} \mathrm{Cl}\right)$ dan metil violet $\left(\mathrm{C}_{24} \mathrm{H}_{27} \mathrm{~N}_{3} \mathrm{HCl}\right)$ sehingga proses degradasi warna oleh mikroorganisme indigenous yang ada di air maupun akar tumbuhan lebih cepat. Zat dapat direduksi dan dapat dipecah rantai ikatannya dengan bantuan mikroorganisme pengurai. Proses awal yang terjadi yaitu mendegradasi senyawa rantai panjang penyusun zat menjadi rantai pendek yang kemudian dapat dimanfaatkan sebagai sumber energi bagi tumbuhan untuk sintesis komponen-komponen penyusun sel baru (Carliell et al. 1995). Hal ini diperkuat dari analisis uji sel, bahwa pada akar E.crassipes telah terjadi penyerapan ketiga warna tersebut (rhodamin B, metilen biru dan metil violet). Semakin lama waktu pemaparan maka persentase penyisihan warna oleh tumbuhan E.crassipes semakin meningkat, hal ini dikarenakan adanya waktu kontak yang lebih lama antara akar tumbuhan dengan limbah dalam reaktor uji phytotreatment.

\section{KESIMPULAN/RINGKASAN}

Berdasarkan pembahasan diatas, maka kesimpulan dalam penelitian ini adalah nilai LC-50 tumbuhan E.crassipes dan pewarna rhodamin B sebesar $99,5 \mathrm{mg} / \mathrm{L}$, metilen biru sebesar $74,5 \mathrm{mg} / \mathrm{L}$, metil violet sebesar $83,2 \mathrm{mg} / \mathrm{L}$. Secara keseluruhan dari hasil uji toksisitas ketiga warna tersebut, dapat disimpulkan bahwa tumbuhan E.crassipes memiliki ketahanan respons biologis yang lebih besar. Efisiensi penyisihan warna pada hari ke 30, pada tumbuhan E.crassipes terhadap warna metilen biru mencapai $59 \%$ sedangkan pada kontrol mencapai $59 \%$, warna rhodamin B mencapai $52 \%$ dan pada kontrol mencapai $52 \%$ dan metil violet sebsar $51 \%$ sedangkan pada kontrol mencapai $51 \%$. Secara keseluruhan dapat disimpulkan bahwa tumbuhan E.crassipes tidak efektif digunakan dalam fitopengolahan warna rhodamin $\mathrm{B}$, metilen biru dan metil violet karena persentase penyisihan tidak berbeda dengan penyisihan pada reaktor kontrol pada hari ke 30 pemaparan dikarenakan adanya mikroorganisme indigenous yang lebih berperan dan terjadinya reduksi oksidasi terhadap pewarna sintesis.

\section{DAFTAR PUSTAKA}

[1] Gercel, O., Gercel, H. F., Koparal, A. S. and U.B.Outveren (2008) Removal of disperse dye from aqueous solution by novel adsorbent prepared from biomass plant material. Journal of Hazardous Materials, 160: 668-674.

[2] Mall, I.D. , Srivastva, V. C., Kumar, G. V. A. and I. M. Mishra., 2006. Characterization of mesoporous fertilizer plant waste carbon for adsorptive removal of dyes from aqueous solution. Colloids and Surfaces. 278: 175-187.

[3] Suteu, D.; Zaharia, C. \& Malutan, T. 2011. Removal of Orange 16 reactive dye from aqueous solution by wasted sunflower seed shells. Journal of the Serbian Chemical Society, Vol.178, No.3, pp.907-924

[4] Tee, H.C., Seng, C.E., dan Lim Noor, A. Md, P.E. 2009. Performance comparison of constructed wetlands with gravel-and rice husk-based media for phenol and nitrogen removal. Sci. Total Environ, 407, hal. 3563-3571.

[5] Mangkoedihardjo, S dan Samudro. 2010. Fitoteknologi Terapan. Graha Ilmu: Yogyakarta

[6] Kurniawan, M.W., Purwanto,P., dan Sudarso,S. 2013. Stratergi Pengelolaan Air Limbah Sentra UMKM Batik yang Berkelanjutan di Kabupaten Sukoharjo . Jurnal Ilmu Lingkungan, 11(2), hal. 62-72.

[7] Mukti, A.M. 2008. Penggunaan Tumbuhan Eceng Gondok (Eichornia crassipess) Sebagai Pre Treatmen Pengolahan Air Minum Pada Air Selokan Mataram. Tugas Akhir untuk Memperoleh Gelar Sarjana, UII, Yogyakarta.

[8] Dhir, B., Sharmila, P., Saradhi, P.P. (2009) 'Potential of Aquatic Macrophytes for removing

[9] Gunnarsson, C.C. dan Petersen, C.M. (2007). Water Hyacinths as A Resource in Agriculture and Energy Production: A Literature Review. Waste Management No.27, hal.117-129. Elsevier Ltd.

[10] Kah, A., Norhashimah, M., Jie, Q., 2016. Phytoremediation of Methylene Blue and Methyl Orange Using Eichhornia crassipes. International Journal of Environmental Science and Development, Vol. 7, No. 10

[11] Suelee, A. L. 2015. Phytoremediation Potential of Vetiver Grass (Vetiverie zozanioides) for Water Contaminated with Selected Heavy Metal. Project Report for the Degree of Bachelor of Environmental Science and Technology, Universiti Putra Malaysia.

[12] Al-Baldawia, I.A.W., Abdullaha, S.R.S., Sujab, F., Anuara, N., Idrisc, M., 2015. The Ratio of Plant Numbers to the Total Mass of Contaminant as One Factor in Scaling-up Phytoremediation Process. Sciences \& Engineering Journal, 74(3), hal. 111-114.

[13] Karenlampi, S.K., Schat, H., Vangronsveld, J., Verkleij, J. A. C., van der Lelie, D., Mergeay, M. Tervahauta A.I. 2000. Genetic Engineering in the Improvement of Plants for Phytoremediation of Metal Polluted Soils. Environ. Pollut, 107, hal 225-231.

[14] Puspita, dkk. 2011. Kemampuan Tumbuhan Air sebagai Agen Fitoremediator Logam Berat Kromium (Cr) yang terdapat pada Limbah Cair Industri Batik.Jurnal Berkala Perikanan Terubuk. Vol 39. No. 1. ISSN 0126-4265.

[15] Simanjuntak, 2014. Uji Toksisitas Ekstrak Daun (Myristica fragrans Houtt) dengan Metodr Brine Shrimp Lethality Test (BSLT) 